\title{
Consumer Behaviour towards Branded and Unbranded Value Added Agricultural Products in Navsari City
}

\author{
Amit Lathiya ${ }^{* 1}$, V.M.Thumar ${ }^{2}$, Kuldeep Choudhari ${ }^{3}$, Gautam Parmar $^{4}$ \\ ${ }^{1}$ Assistant Professor, Planning and Development Cell, Office of the Director of Research and Dean P.G. Studies, \\ Navsari Agricultural University, Navsari (Gujarat). \\ ${ }^{2}$ Planning Officer,Planning and Development Cell, Office of the Director of Research and Dean P.G. Studies, \\ Navsari Agricultural University, Navsari (Gujarat). \\ ${ }^{3}$ Assistant Professor, Aspee Agribusiness Management Institute and Assistant Registrar (Adm.) \\ Navsari Agricultural University, Navsari (Gujarat). \\ ${ }^{4}$ Assistant Professor, Aspee Agribusiness Management Institute, Navsari Agricultural University,
}

Navsari (Gujarat).

\begin{abstract}
The study is an attempt to understand different aspects of consumer preference and behaviour on buying branded and unbranded value added agricultural food products. This study aims to identify the buying preference and behaviour of consumer purchase of branded and unbranded food products. For this study information was collected by semi-structured questionnaire method for selected value added agricultural products from 120 respondents of Navsari city. The result of the study revealed that some of the respondents were give more preference toward branded split pigeon pea $\&$ basmati rice and some of the respondents were give more preference toward unbranded food products like turmeric powder and sugar. In all the categories of products, higher income group $\left(\mathrm{n}_{3}\right)$ respondents tend to purchase branded products as compared to other income groups. It is concluded that education of the respondent's effect their buying behaviour. This study was found that Rantio, Dawat, Ramdev and Madhur are most popular brands of different selected products in Navsari city. Most common source of information for brands is TV/Radio ads followed by friends and relatives and retail shop display respectively. Quality, taste and perceived nutritive value are the top three reasons found for purchase of branded products. Lower income group $\left(\mathrm{n}_{1}\right)$ found to prefer unbranded products as compared to other income groups. Easy availability, lower price and habit found to be most important reasons for purchasing unbranded products. The study will help the manufacturers to make meaningful conclusions on the basis of observations made in the study.
\end{abstract}

Keywords - Consumer Preference; Consumer Behaviour; Branded and Unbranded Value Added Agricultural Products

\section{Introduction}

Consumer behaviour includes the "what-wherewhy-when and how" of the acquisition and knowledge process. As success and failure of selling depends on track consumers, individuals and group reactions expressed within the sort of buying patterns one must understand consumer behaviour. Understanding consumer behaviour and "knowing consumer" isn't simple. Consumers may say something else but do something other. They'll not be intuned with their inner motivations. They may answer influences that change their minds at the eleventh hour. The fashionable marketing concept spells out the important significance of consumer behaviour.

An enormous population of consumers was spending large sums of cash on goods and services. Besides this, consumer preferences were shifting and becoming highly diversified. Even just in case of commercial markets, where the necessity for goods and services is usually more homogenous, buyerse preferences were becoming diversified and that they too were exhibiting less predictable purchase behaviour.

Personal factors also influence buyer behaviour. The important personal factors, which influence buyer behaviours, are Age, Occupation, Income and Life Style. Value addition to agricultural products is that the process of accelerating the value and consumer appeal of an agricultural commodity. We generally consider adding value by appropriate grading and processing of the food products. Value addition can go even beyond this level by packaging or appropriate branding of food products. Building a robust brand is important for simplifying consumer deciding and for reducing risk. A brand may be a name, term, sign, symbol or design wont to identify the products of one firm and to differentiate them from the products of the competitors. A brand or a trade mark is an integral a part of the symbol appearing on the merchandise. A buyer identifies the merchandise with the name and seller gets an opportunity to earn goodwill within the market. 


\section{Objective of the study}

- To study consumer preference towards branded $\mathrm{v} / \mathrm{s}$ unbranded value added agricultural products.

- To study consumer behaviour towards branded $\mathrm{v} / \mathrm{s}$ unbranded value added agricultural products.

\section{Materials and Methods}

The methodology adopted to conduct the investigation is detailed under following to explain the plan of work and sequential procedure. For the present study selected category of Split pigeon pea, Basmati Rice, Turmeric Powder and Sugar have been studied for this purpose.

- Location of survey: Navsari city

- Population/Source of Data: Households of Navsari city

- Sample size: Total 120 samples have been collected from three groups of consumers on the basis of income as follows

- Higher income group: 40

- Middle income group: 40

- Lower income group: 40

- Sampling method: Convenience sampling.

- Data collection: Primary data have been collected from consumers of Navsari city.

- Research Instrument: A semi-Structured Questionnaire.

\section{Results and Discussion}

The result of the present study entitled "Consumer behaviour towards branded and unbranded value added agricultural products in Navsari city" derived through the use of prescribed methodology are presented here.

\subsection{General Information of Selected Respondents}

In the present investigation the general profile studied included gender, age, occupation, family type, education, family income and monthly expenditure on value added agricultural products.

Table 1. Profile of respondents

\begin{tabular}{|l|c|c|}
\hline \multicolumn{3}{|c|}{ Gender of the respondents } \\
\hline Male & Frequency & Percentage \\
\hline Female & 82 & 68.33 \\
\hline \multicolumn{3}{|c|}{ Age of the respondents } \\
\hline Below 18 Yrs & 0 & 31.67 \\
\hline $19-30$ Yrs & 68 & 0.00 \\
\hline $31-50$ Yrs & 42 & 56.67 \\
\hline 51 \& above Yrs & 10 & 35.00 \\
\hline \multicolumn{2}{|c|}{ Education level of respondents } \\
\hline Less than Primary & 0 & 0.33 \\
\hline Primary & 2 & 0.00 \\
\hline
\end{tabular}

\begin{tabular}{|c|c|c|}
\hline Secondary & 11 & 9.17 \\
\hline Higher secondary & 23 & 19.17 \\
\hline UG & 29 & 24.17 \\
\hline PG \& More & 55 & 45.83 \\
\hline \multicolumn{3}{|c|}{ Occupation of respondents } \\
\hline Housewife & 7 & 5.83 \\
\hline Service & 83 & 69.17 \\
\hline Business & 22 & 18.33 \\
\hline Farmer & 3 & 2.50 \\
\hline Retired & 5 & 4.17 \\
\hline \multicolumn{3}{|c|}{ Marital status } \\
\hline Married & 77 & 64.16 \\
\hline Divorce & 0 & 0 \\
\hline Unmarried & 43 & 35.84 \\
\hline \multicolumn{3}{|c|}{ Type of the family } \\
\hline Nuclear & 73 & 60.83 \\
\hline Joint & 47 & 39.17 \\
\hline \multicolumn{3}{|c|}{ Annual Gross Income of the family } \\
\hline $\begin{array}{l}\text { Below } 2.5 \text { lakhs } \\
\left(\mathbf{n}_{1}\right)\end{array}$ & 40 & 33.33 \\
\hline $\begin{array}{l}\text { Above } 2.5-7.5 \\
\text { lakhs }\left(\mathbf{n}_{2}\right)\end{array}$ & 40 & 33.33 \\
\hline $\begin{array}{l}\text { Above } 7.5 \text { lakhs } \\
\left(\mathbf{n}_{3}\right)\end{array}$ & 40 & 33.33 \\
\hline \multicolumn{3}{|c|}{ Monthly Expenditure } \\
\hline $500-999$ & 34 & 28.33 \\
\hline 1000-1499 & 25 & 20.83 \\
\hline $1500-2000$ & 33 & 27.50 \\
\hline$>2000$ & 28 & 23.33 \\
\hline
\end{tabular}

The table 1 showed that the different category wise number of respondents (Frequency) and percentage for the respective categories. It revealed that majority of the respondents 68.33 percent were male and rest 31.67 percent of them were female. According to the study 56.67 percent belonged to 19 to 30 years followed by 35.00 percent belonged to 31 to 50 years and remaining 8.33 percent were in the age group of above 50 years.

As revealed from the table 1 maximum number of respondents $(45.83$ percent) were post-graduate $\&$ more followed by 24.17 percent were under graduate education, 19.17 percent were higher secondary and 9.17 percent were secondary. Very less i.e. 1.67 percent of the respondents were completed primary school education.

The family type constitutes both nuclear and joint family. The table showed that majority of the respondents (60.83 percent) belonged to joint family and remaining 39.17 percent belonged to nuclear family, which showed that nuclear family system is gradually disintegrating from the society. Out of total sample with majority 69.17 percent were service holders followed by 18.33 percent were business, 5.83 percent housewives, 4.17 percent retired and only 2.50 percent were farmers by their occupation. Most of the respondents were educated which may be due to the presence of college and school in the nearby area as well as 
good transportation facility in that area. The table showed that three groups of respondents according to their annual income. The sample size of all three groups was same $(33.33 \%)$

From the table we can also found out that monthly expenditure of consumers on the value added agricultural products were 28.33 percent belonged to the range of 500999 Rs followed by 27.53 percent belonged to the range of 1500-2000 Rs, 23.33 percent belonged to the range of more than 2000 Rs and 20.83 percent belonged to the range of 1000-1499 Rs.

Table 2: Buying preference of consumers towards the branded and unbranded value added agricultural products

\begin{tabular}{|c|c|c|c|c|c|}
\hline & \multirow{2}{*}{$\begin{array}{c}\text { N } \\
\text { o }\end{array}$} & \multirow{2}{*}{ Products } & \multicolumn{2}{|c|}{$\begin{array}{c}\text { No. of } \\
\text { respondent } \\
\text { using Branded } \\
\text { products }\end{array}$} & \multicolumn{2}{c|}{$\begin{array}{c}\text { No. of } \\
\text { respondent } \\
\text { using } \\
\text { unbranded } \\
\text { products }\end{array}$} \\
\cline { 3 - 6 } & \multicolumn{2}{|c|}{$\begin{array}{c}\text { Freque } \\
\text { ncy }\end{array}$} & $\begin{array}{c}\text { Percen } \\
\text { tage }\end{array}$ & $\begin{array}{c}\text { Freque } \\
\text { ncy }\end{array}$ & $\begin{array}{c}\text { Perce } \\
\text { ntage }\end{array}$ \\
\hline 1 & $\begin{array}{c}\text { Split Pigeon Pea } \\
\text { (Toor dal) }\end{array}$ & 63 & 52.5 & 57 & 47.5 \\
\hline 2 & Basmati Rice & 84 & 70.0 & 36 & 30.0 \\
\hline 3 & Turmeric powder & 45 & 37.5 & 75 & 62.5 \\
\hline 4 & Sugar & 58 & 48.33 & 62 & 51.67 \\
\hline
\end{tabular}

Table 2 showed that buying preference of consumers towards branded and unbranded value added agricultural product. From the table 2 observed that the number of respondents for using branded product was higher in split pigeon pea $(52.5 \%)$ and basmati rice $(70 \%)$ where lesser in turmeric powder(37.5\%) and sugar(48.33\%) as compare to the number of respondents for using unbranded products.

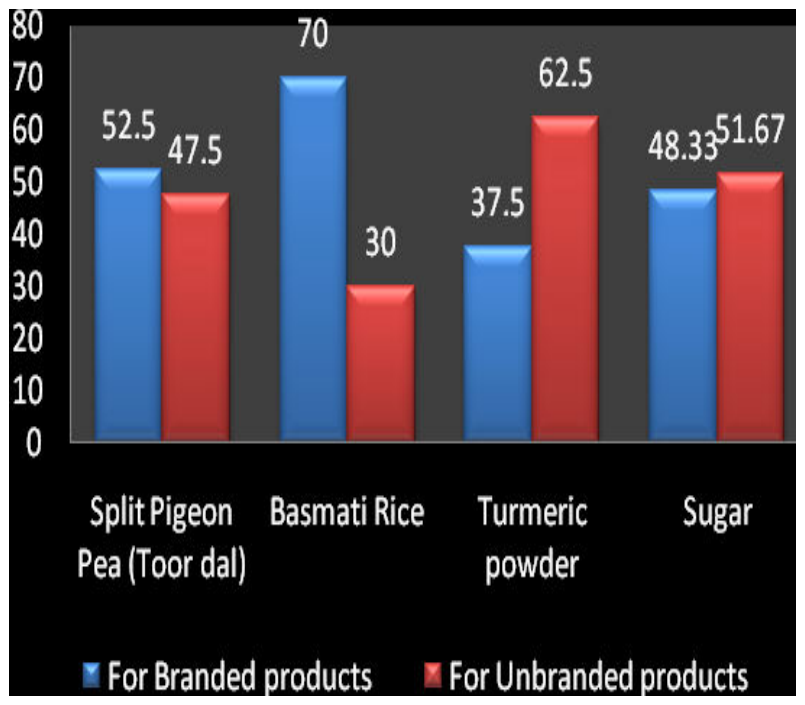

Fig. 1: showed that the percentage of respondents for using branded and unbranded value added agricultural products
Table 3: Income group wise classification of branded users

\begin{tabular}{|c|c|c|c|c|c|}
\hline \multirow{2}{*}{$\begin{array}{c}\text { N } \\
\mathbf{0}\end{array}$} & \multirow{2}{*}{ Products } & \multicolumn{3}{|c|}{ No. of respondent for Branded products } \\
\cline { 3 - 6 } & $\mathbf{n}_{1}$ & $\mathbf{n}_{2}$ & $\mathbf{n}_{3}$ & $\begin{array}{c}\text { Tot } \\
\text { al }\end{array}$ \\
\hline 1 & $\begin{array}{c}\text { Split Pigeon } \\
\text { Pea (Toor } \\
\text { dal) }\end{array}$ & $13(20.63)$ & $20(31.75)$ & $30(47.62)$ & 63 \\
\hline 2 & $\begin{array}{c}\text { Basmati } \\
\text { Rice }\end{array}$ & $26(30.95)$ & $28(33.33)$ & $30(35.71)$ & 84 \\
\hline 3 & $\begin{array}{c}\text { Turmeric } \\
\text { powder }\end{array}$ & $07(15.55)$ & $12(26.67)$ & $26(57.78)$ & 45 \\
\hline 4 & Sugar & $12(20.69)$ & $21(36.21)$ & $25(43.10)$ & 58 \\
\hline
\end{tabular}

Note: $n_{1}$-Lower income group, $n_{2}$-Middle income group, $n_{3}-$ Higher income group

Table 3 indicates that the group wise no. of respondents for using branded product for the different value added agricultural products. Higher no. of respondents was observed $n_{3}$ group for all four selected products which indicate the higher income group.

Table 4: Brand preference for value added agricultural products

\begin{tabular}{|c|c|c|c|c|c|c|}
\hline \multirow[t]{2}{*}{$\begin{array}{l}\text { Sr } \\
\text { No }\end{array}$} & \multirow[t]{2}{*}{ Products } & \multicolumn{3}{|c|}{$\begin{array}{l}\text { Top Three Preferred Brand } \\
\text { with no. of respondents }\end{array}$} & \multirow{2}{*}{ 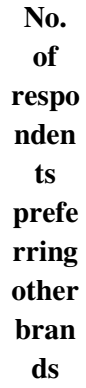 } & \multirow[b]{2}{*}{$\begin{array}{l}\text { Tc } \\
\text { ta }\end{array}$} \\
\hline & & 1 & 2 & 3 & & \\
\hline 1 & $\begin{array}{c}\text { Split } \\
\text { Pigeon } \\
\text { Pea (Toor } \\
\text { dal) }\end{array}$ & $\begin{array}{l}\text { Rantio } \\
(21)\end{array}$ & $\begin{array}{c}\text { Angoor } \\
\text { (12) }\end{array}$ & $\begin{array}{l}\text { Laxmi } \\
(10)\end{array}$ & 20 & 63 \\
\hline 2 & $\begin{array}{l}\text { Basmati } \\
\text { Rice }\end{array}$ & $\begin{array}{l}\text { Dawat } \\
(29)\end{array}$ & $\begin{array}{c}\text { Fortune } \\
\text { (18) }\end{array}$ & $\begin{array}{l}\text { India } \\
\text { gate } \\
(16)\end{array}$ & 21 & 84 \\
\hline 3 & $\begin{array}{l}\text { Turmeric } \\
\text { powder }\end{array}$ & $\begin{array}{c}\text { Ramdev } \\
\text { (09) }\end{array}$ & $\begin{array}{c}\text { Everest } \\
(06)\end{array}$ & $\begin{array}{c}\text { Tata } \\
\text { sampan } \\
(04)\end{array}$ & 26 & 45 \\
\hline 4 & Sugar & $\begin{array}{l}\text { Madhur } \\
\text { (12) }\end{array}$ & $\begin{array}{c}\text { Relianc } \\
\text { e Good } \\
\text { life (09) }\end{array}$ & $\begin{array}{c}24 \\
\text { mantra } \\
\text { organic } \\
(04)\end{array}$ & 33 & 58 \\
\hline
\end{tabular}

Table 4 showed that the consumers were given preference towards the different brands for the different products. This shows that Rantio, Dawat, Ramdev and Madhur are most popular brands of different selected products in Navsari city. 
Table 5: Sources of information about branded value added agricultural products

\begin{tabular}{|c|c|c|c|c|}
\hline No & Particulars & Frequency & Percentage & Rank \\
\hline 1 & $\begin{array}{c}\text { Retail shop } \\
\text { display }\end{array}$ & 42 & 35 & 3 \\
\hline 2 & $\begin{array}{c}\text { Friends \& } \\
\text { Relatives }\end{array}$ & 61 & 50.83 & 2 \\
\hline 3 & $\begin{array}{c}\text { Newspaper \& } \\
\text { Magazine }\end{array}$ & 39 & 32.5 & 4 \\
\hline 4 & Internet & 32 & 26.66 & 5 \\
\hline 5 & TV/Radio Ads & 68 & 56.66 & 1 \\
\hline 6 & Others & 14 & 11.66 & 6 \\
\hline
\end{tabular}

Note: Multiple responses

An information source may be a person, thing, or place from which information comes, arises, or is obtained. That source might then inform an individual about something or provide knowledge about it. Advertising is an audio or visual sort of marketing communication that employs an openly sponsored, nonpersonal message to market or sell a product, service or idea.It is communicated through various mass media including traditional media such as retail shop display, friends \& relatives, news papers\& magazines, internet, television\& radio and other advertising.

Table 5 showed that majority respondents were got the information through the TV \& Radio ads (56.66 \%) followed by friends \& relatives $(50.83 \%)$, retail shop display $(35 \%)$ and so on. The rank was given by decreasing order. The consumers purchasing decision is influenced by cultural, social, personal and psychological factors. Table 6 showed that consumers' perception on brand choice based on some factors or reasons. Few of them are taken for analysis and those are readily availability, quality, perceived nutritive value, taste, value for money, discount, scheme \& offers, attractive packaging and recommendation of retailers for branded value added products.

Table 6: Reasons for purchase of branded value added agricultural products

\begin{tabular}{|c|c|c|c|c|}
\hline No & Reasons & Frequency & Percentage & Rank \\
\hline 1 & Readily available & 19 & 15.83 & 6 \\
\hline 2 & Quality & 88 & 73.33 & 1 \\
\hline 3 & $\begin{array}{c}\text { Perceived } \\
\text { nutritive value }\end{array}$ & 69 & 57.5 & 3 \\
\hline 4 & Taste & 72 & 60 & 2 \\
\hline 5 & Value for money & 26 & 21.66 & 5 \\
\hline 6 & $\begin{array}{c}\text { Discount, } \\
\text { scheme \& offers }\end{array}$ & 33 & 27.5 & 4 \\
\hline 7 & $\begin{array}{c}\text { Attractive } \\
\text { packaging }\end{array}$ & 10 & 8.33 & 8 \\
\hline 8 & $\begin{array}{c}\text { Recommendation } \\
\text { of retailers }\end{array}$ & 14 & 11.66 & 7 \\
\hline
\end{tabular}

Note: Multiple responses
It was inferred from table 6 that $73.33 \%$ respondents considered the quality of food items was very important and ranked one. Test was also seen as a very important factor and ranked two $60 \%$ respondents agreed on this. Similarly to perceived nutritive value, $57.5 \%$ respondents were an influencing factor while purchase of branded products which was ranked as three. Discount, scheme \& offers, value for money, ready availability, recommendation of retailers and attractive packaging were also the influencing factors while purchasing the branded product as perceived by the respondents.

Table 7: Behaviour of consumers when particular brand is not available

\begin{tabular}{|c|c|c|c|c|}
\hline No & Particulars & $\begin{array}{c}\text { No of } \\
\text { respondents }\end{array}$ & Percentage & Rank \\
\hline 1 & $\begin{array}{c}\text { Drop the idea } \\
\text { of buying } \\
\text { products }\end{array}$ & 9 & 7.5 & 5 \\
\hline 2 & $\begin{array}{c}\text { Go to another } \\
\text { retail outlet }\end{array}$ & 70 & 58.33 & 1 \\
\hline 3 & $\begin{array}{c}\text { Try another } \\
\text { brand }\end{array}$ & 63 & 52.5 & 2 \\
\hline 4 & $\begin{array}{c}\text { Ask the retailer } \\
\text { to make the } \\
\text { brand available } \\
\text { in few days }\end{array}$ & 30 & 25 & 3 \\
\hline 5 & $\begin{array}{c}\text { Switch to } \\
\text { Unbranded } \\
\text { Products }\end{array}$ & 25 & 20.83 & 4 \\
\hline
\end{tabular}

Note: Multiple responses

The table 7 shows that behaviour of consumers when particular brand is not available then 58.33 percent respondents were go to another retail outlet, 52.50 percent were try another brand, 25 percent were wait for few days, 20.83 percent were switch to unbranded products and very few percent(7.50) were drop the idea of buying the products. Rank was given by decreasing order.

Table 8: Income group wise classification of unbranded product users

\begin{tabular}{|c|c|c|c|c|c|}
\hline \multirow{2}{*}{$\begin{array}{c}\text { N } \\
\mathbf{0}\end{array}$} & \multirow{2}{*}{ Products } & \multicolumn{4}{|c|}{ No. of respondent for Unbranded products } \\
\cline { 3 - 6 } & $\mathbf{n 1}$ & $\mathbf{n 2}$ & $\mathbf{n 3}$ & $\begin{array}{c}\text { Tota } \\
\text { I }\end{array}$ \\
\hline 1 & $\begin{array}{c}\text { Split } \\
\text { Pigeon Pea } \\
\text { (Toor dal) }\end{array}$ & $27(47.37)$ & $20(35.09)$ & $10(17.54)$ & 57 \\
\hline 2 & $\begin{array}{c}\text { Basmati } \\
\text { Rice }\end{array}$ & $14(38.39)$ & $12(33.33)$ & $10(27.28)$ & 36 \\
\hline 3 & $\begin{array}{c}\text { Turmeric } \\
\text { powder }\end{array}$ & $33(44.00)$ & $28(37.33)$ & $14(18.67)$ & 75 \\
\hline 4 & $\begin{array}{c}\text { Sugar } \\
\text { nyyyyy}\end{array}$ & $26(41.95)$ & $19(30.64)$ & $17(27.41)$ & 62 \\
\hline
\end{tabular}

Note: $\mathrm{n}_{1}$ - Lower income group, $\mathrm{n}_{2}-$ Middle income group, $\mathrm{n}_{3}-$ Higher income group 
Table 8 indicates that the group wise no. of respondents for using unbranded product for the different value added agricultural products. Higher no. of respondents was observed $n_{1}$ group for all four selected products which indicate the lower income group.

Table 9: Reasons for purchase of unbranded value added agricultural products

\begin{tabular}{|c|c|c|c|c|}
\hline No & Reasons & Frequency & Percentage & Rank \\
\hline 1 & $\begin{array}{c}\text { Easily } \\
\text { available }\end{array}$ & 50 & 41.67 & 1 \\
\hline 2 & Taste & 14 & 11.67 & 5 \\
\hline 3 & $\begin{array}{c}\text { Price is } \\
\text { comparatively } \\
\text { low than } \\
\text { Branded }\end{array}$ & 43 & 35.83 & 2 \\
\hline 5 & $\begin{array}{c}\text { Habit as using } \\
\text { since long }\end{array}$ & 20 & 16.67 & 3 \\
\hline 5 & Quality & 06 & 5.00 & 6 \\
\hline 6 & $\begin{array}{c}\text { Local Product } \\
\text { meet their } \\
\text { needs }\end{array}$ & 17 & 14.67 & 4 \\
\hline
\end{tabular}

Note: Multiple responses

From the table 9, it can be observed that the some reasons for consumers were purchase of unbranded value added agricultural products. Out of the total sample 41.67 percent respondents were believed in products are easily available, 35.83 percent respondents were believed in low price than branded, 16.67 percent respondents were believed in habit, 14.67 percent respondents were believed in local product meet their needs, 11.67 percent respondents were believed in taste and very few 5 percent respondents were believed in quality.

\section{Conclusion}

It is found that more number of respondents are using branded toor dal and Basmati Rice, while in usage of turmeric powder and sugar, tendency to buy unbranded or commodity products is dominating. In all the categories of products, higher income group $\left(\mathrm{n}_{3}\right)$ respondents tend to purchase branded products as compared to other income groups. Most common source of information for brands is TV/Radio ads followed by friends and relatives and retail shop display respectively. Quality, taste and perceived nutritive value are the top three reasons found for purchase of branded products. Lower income group $\left(\mathrm{n}_{1}\right)$ found to prefer unbranded products as compared to other income groups. Easy availability, lower price and habit found to be most important reasons for purchasing unbranded products.

\section{References}

[1] Gupta, R. and Jain, V. K. (2014). A study of consumer behavior towards branded food products in urban and rural areas in India, IJMBS, 2(4): 42-47.

[2] Jafersadhiq, A.(2014). A Study on Buying Behavior on Instant Food products at Coimbatore, Research Script, International Journal of Management andHumanities, 1: 26-29.

[3] Mahalaxmi, K.,Pande, V. S., and Mayuresh, M. (2012).Determinants of Consumer Behavior towards Branded \& Unbranded Products.SIT Journal of Management, 2(2): 122-138.

[4] Rajakumari, D. (2011). Consumer Satisfaction over Branded and Unbranded Rice In Salem City. Cauvery Research Journal, 4(1 \& 2): 44-46.

[5] Saipadma, P. (2018.). A Study on Rural Consumer Buying BehaviorTowards Branded Food Products, M.Sc. (Home Sci.) Thesis, Department Of Family Resource Management, College Of Community Science, Orissa University of Agriculture and Technology, Bhubaneswar, Odisha.

[6] Srinivasan, K. and Nirmala, R. (2014). A study on consumer behavior towards instantfood products, IOSR Journal of Business and Management, 11(16): 17-21.

[7] VibhutiTyagi, A. K. and Pandey, V. (2014). A case study on buying behavior towardsselected branded food products, International Journal of Scientific Researchand Management, 8(2): 1168-1182.

[8] Yuvarani, R. (2013). A study on rural consumer behavior towards selected branded foodproducts in Salem district, International Journal of Scientific Research, 2(2):44-45. 